\title{
Pengaruh Bentuk Bukaan Pada Lantai Bangunan Terhadap Tingkat Kenyamanan Termal Pada Rumah Panjang Suku Dayak Brusu Kecamatan Sekatak Provinsi Kalimantan Utara
}

\author{
Eko Wahyudi ${ }^{1}$, Sholehah ${ }^{2}$ \\ ${ }^{1,2}$ Program Studi Teknik Arsitektur, Fakultas Teknik Universitas Kaltara \\ E-mail : ${ }^{1}$ ekowyd3112@gmail.com, ${ }^{2}$ sholehahsuryanata@gmail.com
}

Received 18 September 2019; Reviewed 27 September 2019; Accepted 23 November 2019

Journal Homepage: http://jurnal.borneo.ac.id/index.php/borneoengineering

\begin{abstract}
The longhouse is a home for Brusu Dayak tribes who live in North Kalimantan, which always develops as the building length increases following the increase in the number of family heads in one family. Compared to other Dayak houses, long brusu Dayak tribes have no windows but rely solely on openings on the roof and openings on the building floor as ventilation ventilation. This affects the thermal comfort of the longhouse. In general, this study aims to determine how much influence the shape of the openings on the floor of the brusu dayak longhouse building on the level of thermal comfort.The method in this study includes direct observation of the spaciousness of the shape of the building and the shape of the floor openings in the longhouse, as well as direct measurement at several points that have been determined, namely: measurement of temperature, humidity, air movement using several measuring devices, namely: thermometer, anemometer, hygro thermometer and iinfrared thermometer, measurements are made on the interior of a long house with 15 measuring points, where each point is measured for 24 hours with a measurement time every 2 hours. The results of this study note that the shape of the openings on the floor affects the level of thermal comfort in the longhouse, this is evidenced when the condition of the floor hole is closed there is an increase in the effective temperature in the room even though the increase in the effective temperature is not significant.
\end{abstract}

Keywords: Longhouses, floors, thermal comfort

\begin{abstract}
Abstrak
Rumah panjang merupakan rumah bagi masyarakat suku dayak brusu yang bermukim di Kalimantan Utara yang selalu berkembang dengan bertambah panjangnya bangunan tersebut mengikuti bertambahnya jumlah kepala keluarga dalam satu keturunan. Jika dibandingkan dengan rumah-rumah suku dayak lainnya, pada rumah panjang suku dayak brusu tidak memiliki jendela melainkan hanya menghandalkan bentuk bukaan pada atap dan bukaan pada lantai bangunan saja sebagai ventilasi penghawaan. Hal ini berpengaruh terhadap kenyamanan termal pada rumah panjang tersebut. Secara umun penelitian ini bertujuan untuk mengetahui seberapa besar pengaruh bentuk bukaan pada lantai bangunan rumah panjang suku dayak brusu terhadap tingkat kenyamanan termal. Metode dalam penelitian ini meliputi observasi langsung kelapangan terhadap bentuk bangunan dan bentuk bukaan lantai pada rumah panjang tersebut, serta melakukan pegukuran langsung dibeberapa titik yang telah ditentukan, yaitu : pengukuran temperatur, kelembaban, pergerakan udara dengan menggunakan beberapa alat ukur, yaitu : thermometer, anemometer, hygro thermometer dan iinfrared thermometer, pengukuran dilakukan pada interior rumah panjang dengan 15 titik ukur, dimana setiap titik diukur selama 24 jam dengan waktu pengukuran setiap 2 jam sekali. Hasil penelitian ini diketahui bahwa bentuk bukaan pada lantai berpengaruh terhadap tingkat kenyamanan termal pada rumah panjang tersebut, hal ini dibuktikan pada saat kondisi lubang lantai ditutup terjadi peningkatan temperatur efektif pada ruang meskipun peningkatan temperatur efaktif tersebut tidak signifikan.
\end{abstract}

Kata kunci: Rumah Panjang, lantai, kenyamanan termal 


\section{Pendahuluan}

Rumah Panjang suku dayak brusu merupakan salah satu rumah tradisional suku dayak yang berada di Provinsi Kalimantan Utara, tepatnya di Kecamatan Sekatak Kabupaten Bulungan. Rumah ini dengan bentuknya yang memanjang sesuai dengan jumlah kepala keluarga yang tinggal di rumah panjang tersebut dan tidak memiliki jendela hanya memiliki dua buah pintu pada sisi sebelah kanan dan kiri pada bangunan tersebut, sehingga untuk sistem penghawaan hanya menghandalkan bukaan pada bentuk atap dan lubang pada lantai yang fungsi utamanya adalah sebagai lubang buangan tumpahan air dari tempayan saat acara adat berlangsung (Wahyudi 2016 \& 2017). Sehingga harus perlu pembuktian apakah dengan adanya bukaan pada lantai tersebut, kenyamanan thermal pada bangunaan terpenuhi.

Sebagai tindaklanjut penelitian sebelumnya terkait pengaruh bukaan pada atap bangunan terhadap tingkat kenyamanan termal, penelitian ini bertujuan untuk mengetahui pengaruh bentuk bukaan pada lantai bangunan rumah panjang suku dayak brusu terhadap tingkat kenyamanan termal.

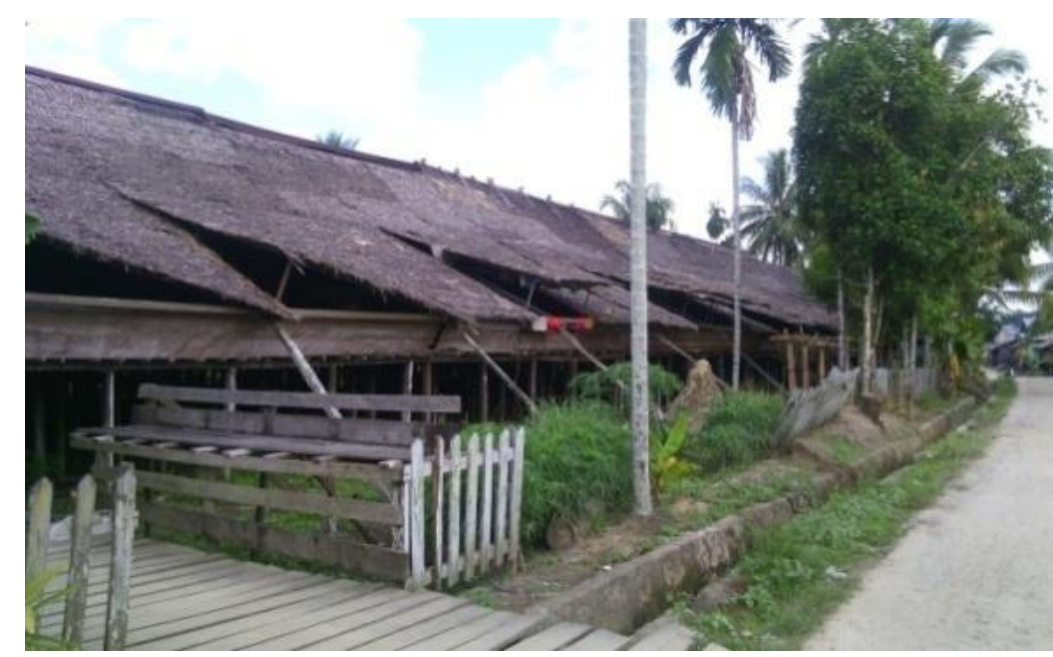

Gambar 1. Rumah Panjang Dayak Brusu

\section{Metode Penelitian}

Metode penelitian meliputi observasi langsung ke lapangan terhadap bentuk bangunan dan bentuk bukaan pada lantai pada rumah panjang tersebut, serta melakukan pegukuran langsung dibeberapa titik yang ditentukan. Pengukuran yang dilakukan antara lain pengukuran temperatur, kelembaban, pergerakan udara.

Pengukuran dilaksanakan pada setiap 2 jam sekali selama 24 jam dilakukan pada ruang salog dan ruang lamin, dengan kondisi atap terbuka disetiap lebar 2 meter dari atap rumah panjang tersebut, serta dengan kondisi lubang lantai terbuka dan tertutup dengan target data ukur yang diambil adalah :

- Temperatur

- Kelembaban

- Pergerakan Udara 


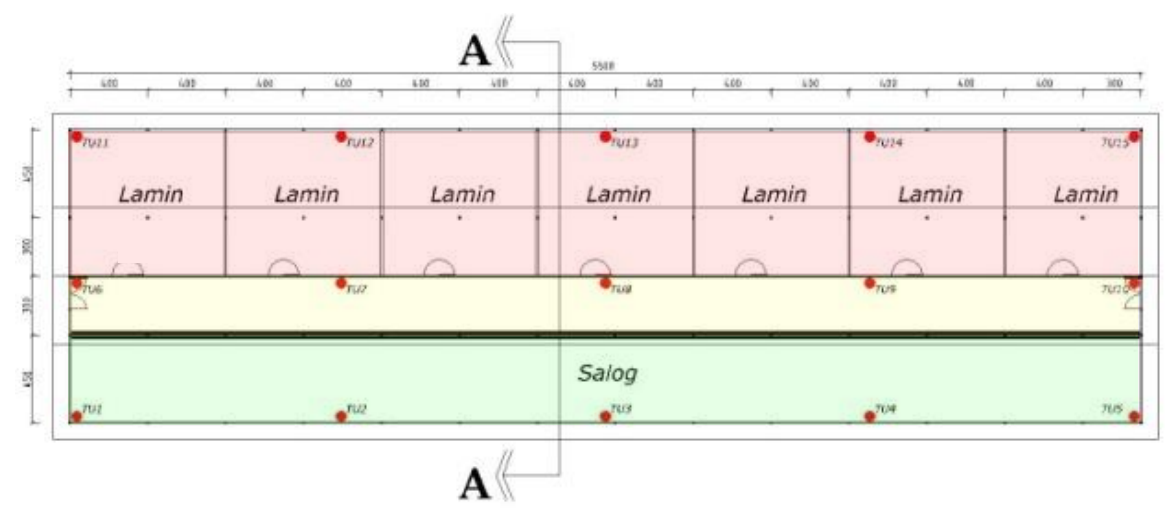

Gambar 2. Denah Titik Ukur Pada Rumah Panjang

\section{Tinjauan Pustaka}

\subsection{Arsitektur dan Kebudayaan}

Menurut (Rapoport 1969), membagi perkembangan awal terbentuknya pola kebudayaan dan arsitektur sebagai berikut :

1. Primitive, di tandai dengan adanya variasi dalam tipe bangunan yaitu similar, karena pada tahap ini membangun rumah merupakan pengetahuan umum Yang dikatahui semua orang. Pada pola tahap ini sudah ada kesempatan-kesempatan umum tentang bentuk yang adaptif terhadap iklim dan berkembang menjadi bentuk pola kebudayaan yang spesifik pada masingmasing komunitas masyarakat.

2. Peasant, adalah pola yang semakin berkembang, karena setiap individu memiliki keinginanuntuk tampil beda dengan yang lainnya.

3. Tradesman, adalah kebudayaan dimana masing-masing individu memiliki spesialisasi dengan kemampuannya sendiri-sendiri, sehingga pola kebudayaan diadaptasikan untuk memenuhi kebutuhan masing-masing individu.

\subsection{Atsitektur Vernakular}

Arsitektur vernakular merupakan arsitektur yang tumbuh dan berkembang di dalam masyarakat dengan budaya tertentu dari dan oleh rakyat dengan dilatari lingkungan binaan alami, arsitektur venakular merupakan warisan pengetahuan seni membangunan yang berasal dari para pendahulunya atau leluhurnya yang dikaitkan dengan keyakinan masyarakat geomancy, kosmologi, tata nilai kehidupan, hirarki, simbolisme, ornament, dan bentuk arsitektur.

\subsection{Faktor yang mempengaruhi kenyaman}

Indonesia berada pada daerah tropis lembab, yang keadaan iklimnya banyak dipengaruhi oleh kondisi geografis sebagai negara kepulauan dengan ciri-ciri iklim tropis lembab (Soegijanto 1998). Ada beberapa faktor dari iklim yang mempengaruhi kenyamanan suatu bangunan pada daerah tropis (Lippsmeier 1994 \& Rahim 2012), antara lain yaitu :

\subsubsection{Temperatur Ruang}

Kondisi di dalam bangunan sangat dipengaruhi oleh kondisi luar atau iklim setempat, baik yang menyangkut intensitas pemansan radiasi matahari yang berpengaruh langsung pada temperatur, kelembaban dan kecepatan angin (aliran udara). (Soegijanto 1998). Kenyamanan didalam suatu ruang tergantung pada kebudayaan dan istiadat masing-masing manusia, terutama iklim dan 
kelembaban, udara dan radiasi, bentuk dan struktur bangunan, serta warna dan pencahayaan (Heinz dan Hesti 2006).

Prinsip perencanaan berdasarkan kondisi iklim setempat sudah diterapkan pada bangunan tradisional oleh masarakat dahulu (Hardiman 1996). Tetapi penetapan tersebut tidak didasarkan oleh pertimbangan kondisi iklim tersebut melainkan dengan pertimbangan cultural.

\subsubsection{Kelembaban Udara}

Tingginya curah hujan pada suatu daerah mempengaruhi tingginya tingkat kelembaban pada daerah tersebut, ini merupakan salah satu ciri dariderah tropis. Untuk mengukur dan menghitung suhu udara dan kelembaban udara antara lain Hygro-Thermometer, seperti gambar dibawah ini.

Kelembaban yang nyaman untuk ruangan berkisar antara 40-70\%, dengan suhu ruang antara 18$25^{\circ} \mathrm{C}$. pencapaian kelembaban dan suhu nikmat sangat penting mempertinggi kegairahan kerja (Szokolay 1980). Besar persentasi angka kelembaban udara dipengaruhi seberapa besaranya pergerakan udara atau aliran udara tersebut (Wahyudi 2018)

\subsubsection{Gerakan Udara}

Gerakan udara terjadi disebabkan oleh pemanasan lapisan udara yang berbeda-beda. Skalanya berkisar mulai dari angin sepoi-sepoi sampai angin topan dengan kekuatan angin 0 sampai 120 $\mathrm{km} / \mathrm{jam}$ (Skala Beaufort). Besarnya kecepatan angin yang bergerak akan berpegaruh pada tingkat kenyamanan seseorang, dimana kecepatan angin yang melebihi $1.5 \mathrm{~m} / \mathrm{dtk}$ dianggap kurang nyaman (Heinz 2008).

\section{Hasil dan Pembahasan}

Bentuk dan kontruksi kayu dengan atap bahan dasar daun sagu pada rumah panjang suku dayak brusu yang ada di kecamatan sekatak yang berasal dari bahan lokal, sehingga sangat menarik untuk dilakukan penelitian terhadap sensasi termal yang terjadi pada rumah pajang tersebut.

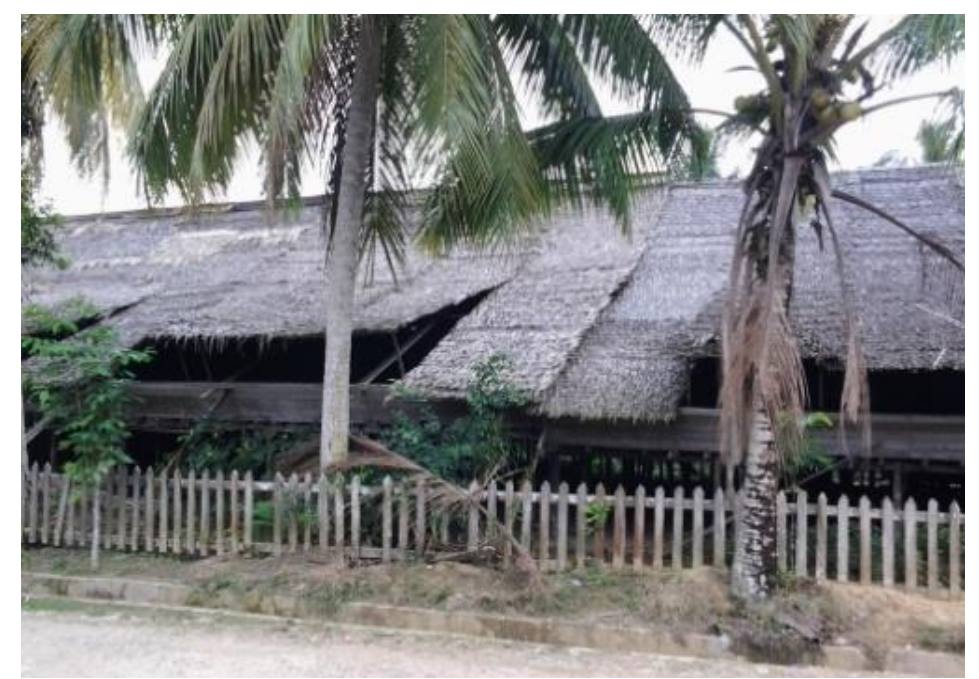

Gambar 3. Rumah Panjang Dayak Brusu 


\subsection{Temperatur Efektif (TE)}

Hasil dari pengolahan data pengukuran dilapangan didapatkan bahwa pada ruang teningkang (salog) yang dilakukan selama 24 jam dengan interval waktu 2 jam sekali didapatkan hasil bahwa temperatur efektif terendah terdapat pada TU5 pada pukul 02.00 WITA dengan temperatur efektif sebesar $25.5^{\circ} \mathrm{C}$. Pada grafik menunjuka bahwa temperatur efektif cendrung mengalami peningkatan hingga pada puncaknya pukul 14.00 WITA, setelah itu mengalami penurunan temperatur efektif secara berlahan.

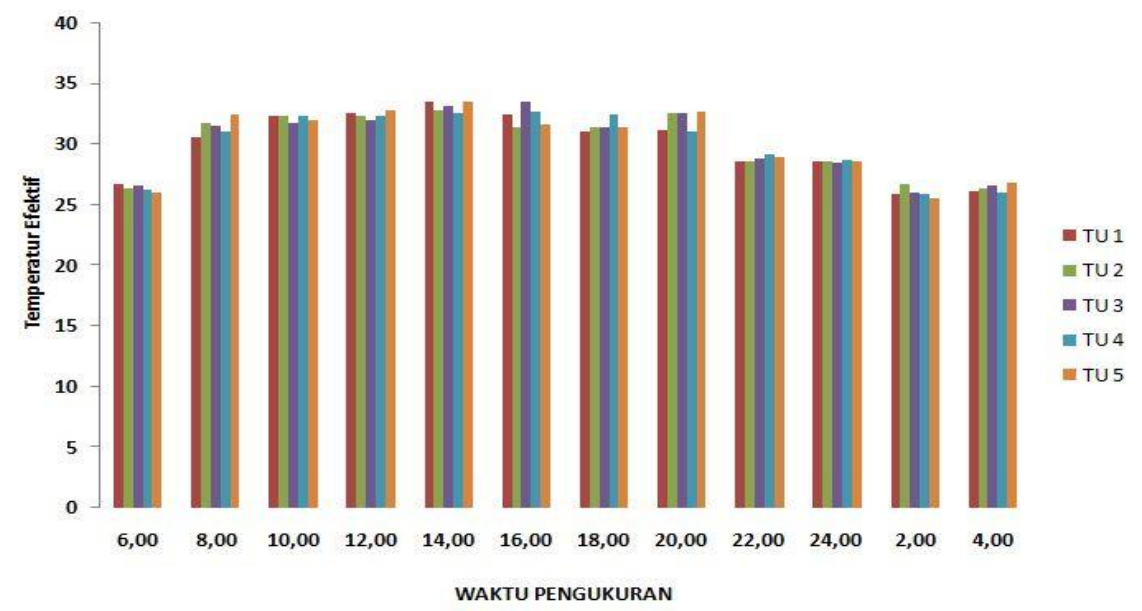

Gambar 4. Perbandingan Temperatur Efektif Pada Ruang Teningkang (Salog)

Dan sebaliknya temperatur efektif tertinggi sebesar $33.4^{\circ} \mathrm{C}$ terdapat pada TU1 dan TU5 pada pukul14.00 WITA serta pada TU3 pada pukul16.00 WITA. TU1 dan TU5 dengan posisi di titik ukur di bagian tepi bangunan disebelah timur dan barat bangunan. Sedangankan TU3 beradi di bagian tengah bangunan sebelah utara dengan kondisi pada ketiga titik ukur tersebut diatas saat pengukuran kondisi atap daun tertutup, sehingga pergerakan udara dititik tersebut tidak maksimal.
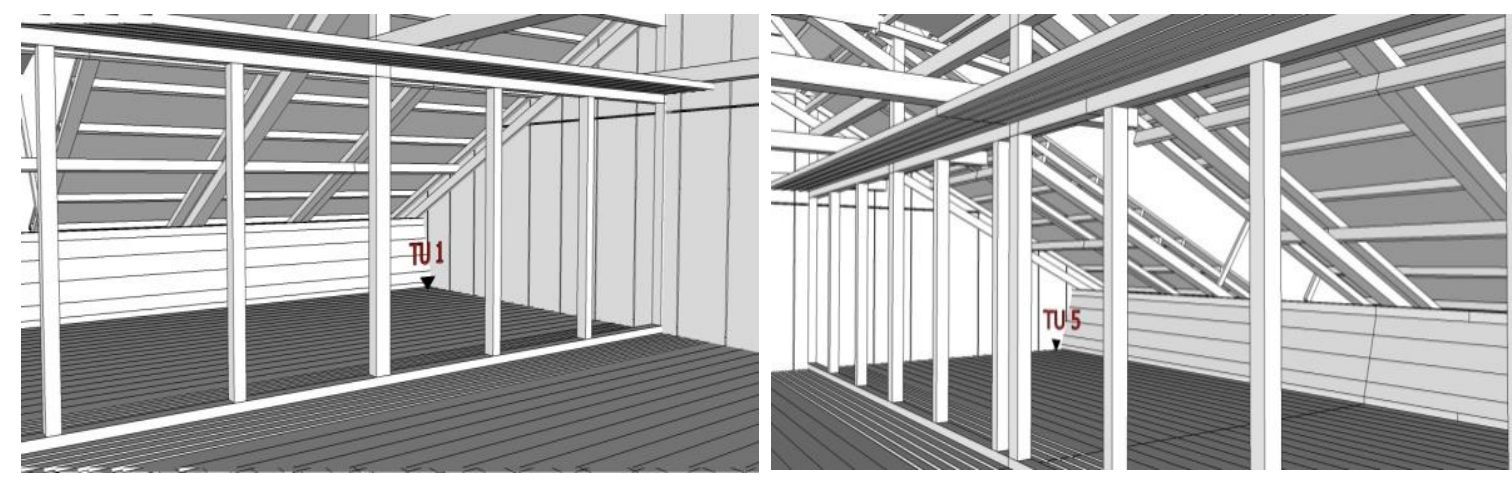

Gambar 5. Kondisi TU1 dan TU5 Pada Ruang Teningkang

Pada ruang ganak (salog) dengan kondisi lubang pada lantai di buka didapat temperatur efektif terendah terdapat pada titik ukur TU10 pada pukul 02.00 WITA sebesar $25,8^{\circ} \mathrm{C}$, dimana posisi tersebut berada pada bangunan disisi Barat dengan kondisi titik berada tepat didepan pintu. Sedangkan untuk temperatur tertinggi pada TU6 pada pukul 14.00 WITA sebesar $34,2^{\circ} \mathrm{C}$ dengan titik ukur berada pada pintu sebelah timur dengan kondisi bukaan yang langsung menghadap rumah warga sehingga udara yang masuk ke dalam bangunan tidak maksimal yang menyebabkan kondisi temperatur efektif pada titik tersebut cukup tinggi. 


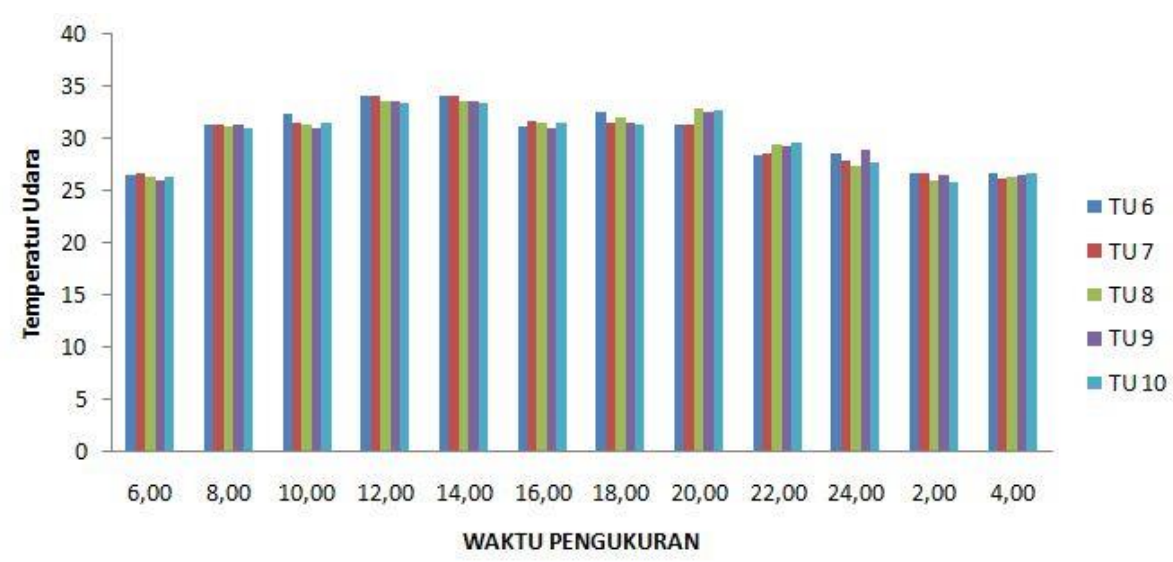

Gambar 6. Perbandingan Temperatur Efektif Pada Ruang Ganak (Salog) Kondisi Lubang Lantai Dibuka

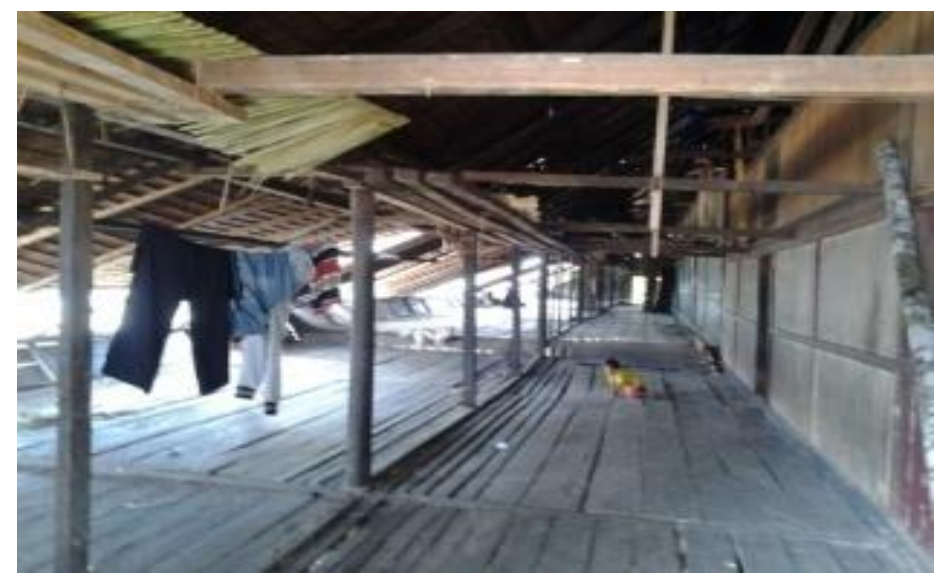

Gambar 7. Kondisi Pada Ruang Ganak (Salog)

Sedangkan temperatur efektif pada ruang ganak (salog) dengan kondisi lubang lantai di tutup, dihasilkan temparatur efektif terendah terdapat pada TU10 pada pukul 02.00 WITA sebesar $25,6^{\circ} \mathrm{C}$ dan temperatur efekif tertinggi terdapat padaTU6 pada pukul 14.00 WITA sebesar $34,2^{\circ} \mathrm{C}$.

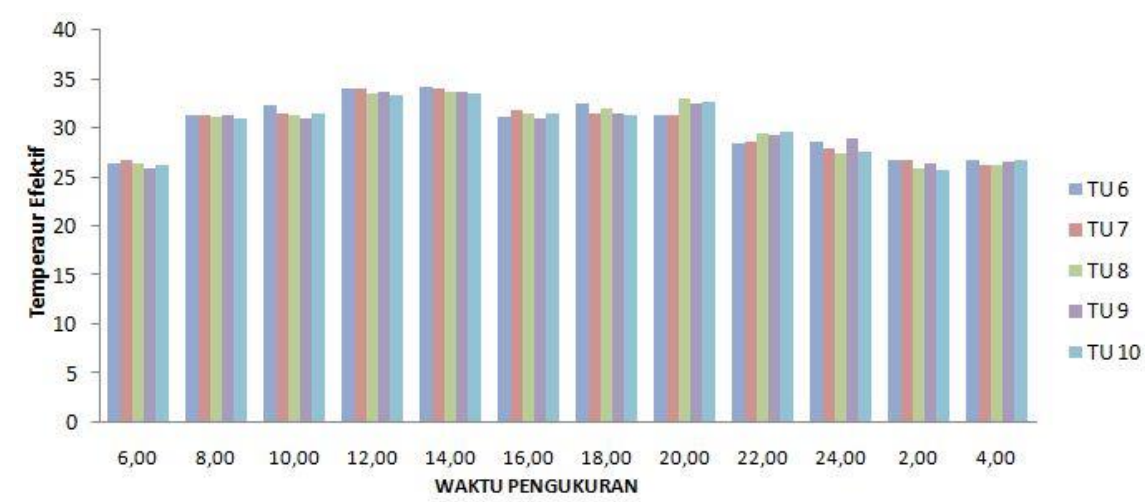

Gambar 8. Perbandingan Temperatur Efektif Pada Ruang Ganak (Salog) Kondisi Lubang Lantai Ditutup 
Dari dua data pengukuran temperatur efektif pada ruang ganak (salog) diatas dengan kondisi lubang pada lantai di buka dan ditutup menunjukan bahwa temperatur efektif pada saat lubang lantai ditutup lebih tinggi dibandingkan pada saat lubang latai di buka.

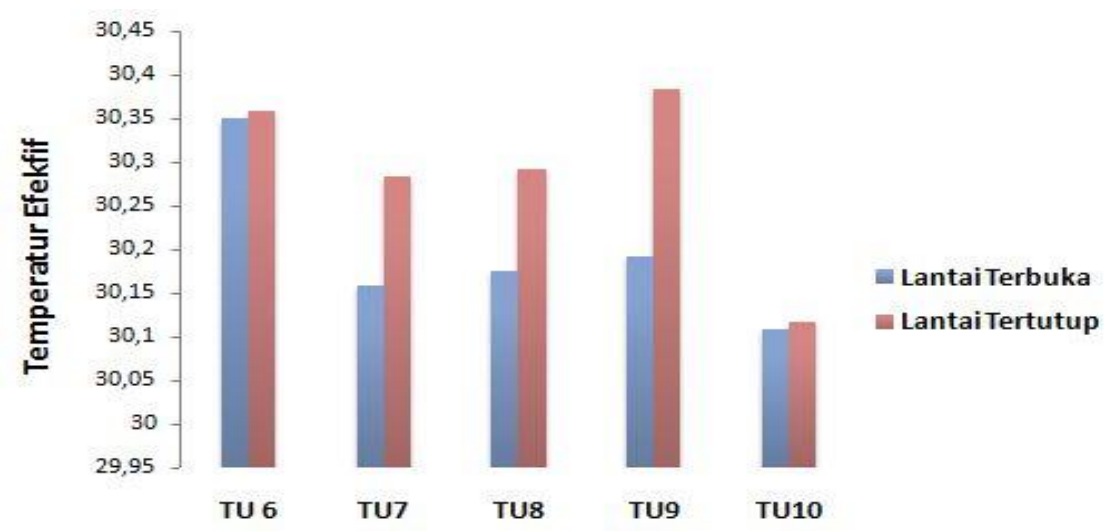

Gambar 9. Perbandingan Temperatur Efektif Pada Ruang Ganak (Salog) Kondisi Lubang Lantai Dibuka dan Ditutup

Hasil pengukuran pada ruang lamin temperatur efektif tertinggi terdapat pada TU11 pukul 12.00 WITA sebesar $34,3^{\circ} \mathrm{C}$ dimana letak titik tersebut posisi disudut bangunan sebelah timur dan pada lamin dengan kondisi atap tertutup, sehingga pergerakan udara yang terjadi sangat kecil.

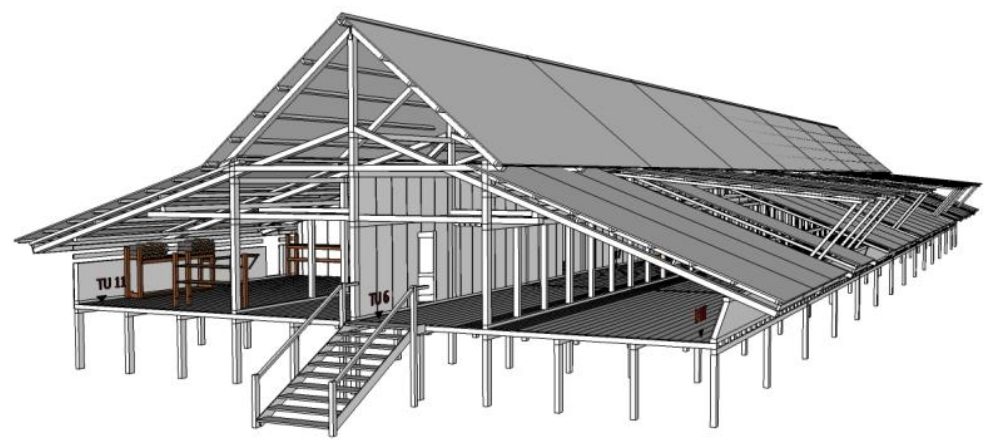

Gambar 10. Kondisi TU11 Pada Ruang Lamin

\section{Kesimpulan}

Dari analisa diatas dapat diambil kesimpulan bahwa temperatur efektif pada ruang ganak (salog) pada saat kondisi lubang pada lantai dibuka lebih rendah jika dibandingkan pada saat kondisi lubang lantai ditutup, hal ini menunjukan bahwa terjadinya perubahan temperatur tersebut dikarenakan adanya pergerakan udara dari bawah lantai kedalam bangunan melalui lubang yang ada pada lantai bangunan. Sehingga dapat disimpulkan bahwa pergerakan udara atau aliran udara berpengaruh terhadap tinggi rendahnya temperatur ruangan tersebut.

Karena letak ruang teningkang (salog) yang berada di sisi bangunan sebelah utara dan bentukan atap rumah panjang yang berada pada teningkang dapat dibuka dan ditutup sesuai dengan kebutuhan penghuninya, sehingga temperatur efektif pada ruang teningkang cendrung lebih rendah dibandingan pada ruang ganak dan lamin. 
Besarnya pergerakan udara atau aliran udara pada rumah panjang akan mempengaruhi besarnya persentasi angka kelembaban udara pada rumah tersebut.

\section{Ucapan Terima Kasih}

Ucapan terima kasih kepada suku dayak brusu sekalimantan utara dan pemilik rumah panjang yang telah memberikan ijin melaksanakan penelitian di rumah panjang. Ucapan terima kasih kepada Kementerian Riset, Teknologi, dan Pendidikan Tinggi yang telah mendanai penelitian ini melalui Hibah Penelitian Dosen Pemula melalui Kontrak Penelitian Tahun Anggaran 2019 117/SP2H/LT/DRPM/2019 dan ucapan terima kasih juga ditujukan kepada semua pihak yang membantu terlaksananya penelitian ini, baik moril maupun materil.

\section{Daftar Pustaka}

Hardiman, Gagoek. Aspek Iklim dan Budaya dalam Arsitektur/Kota Tropis. Jakarta, 1996.

Heinz, Frick. Ilmu Fisika Bangunan. Yogyakarta: Kanisius, 2008.

Heinz, Frick, and Mulyani Tri Hesti. Arsitektur Ekologis. Yogyakarta: Kanisius, 2006.

Lippsmeier, Georg. Bangunan Tropis. Jakarta: Erlangga, 1994.

Rahim, H M Ramli. Fisika Bangunan Untuk Area Tropis. Bogor: IPB Press, 2012.

Rapoport, Amos. House Form and Culture. New Jersey: Prentice Hall Englewood Cliffs, 1969.

Soegijanto. Bangunan di Indonesia Dengan Iklim Tropis Lembab di Tinjau dari Aspek Fisika Bangunan. Jakarta: Direktur Jenderal Pendidikan Tinggi Departemen Pendidikan dan Kebudayaan, 1998.

Szokolay, V. S. Environmental Science Handbook, The Construction. England: Press England, 1980.

Wahyudi, Eko. "Komparasi Tingkat Kenyamanan Termal pada Interior Rumah Panjang Beratap Daun. Studi Kasus : Rumah Panjang Suku Dayak Brusu Kalimantan Utara." LANTING Journal of Architecture, 2016: 1-7.

Wahyudi, Eko. "Komparasi Tingkat Kenyamanan Termal pada Interior Rumah Panjang Suku Dayak Brusu Kalimantan Utara." Jurnal Prokons Malang, 2017: 93-97.

Wahyudi, Eko. "Pengaruh Bentuk Bukaan Atap Bangunan Terhadap Tingkat Kenyamanan Termal Pada Rumah Panjang Suku Dayak Brusu, Kecamatan Sekatak, Kalimantan Utara." Borneo Engineering: Jurnal Teknik Sipil, 2018: 94-104. 